\title{
Competitiveness During Covid-19 Pandemic: New Product Development and Supply Chain Agility
}

\section{Covid-19 Pandemi Döneminde Rekabet Gücü: Yeni Ürün Geliştirme ve Tedarik Zinciri Çevikliği}

\author{
Ahmet ÇETINDAŞ ${ }^{\text {* }}$, Oya ÖZTÜRK ${ }^{\mathrm{b}}$ \\ ${ }^{a}$ Dr. Öğr. Üyesi, Hasan Kalyoncu Üniversitesi, Gaziantep / TÜRKIYE \\ ORCID: 0000-0003-2262-4204.

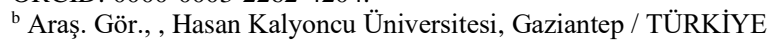 \\ ORCID: 0000-0002-3507-4865.
}

\section{A K A L E B İL G İ İ}

\section{Makale Geçmişi:}

Başvuru tarihi: 30 Ağustos 2020

Kabul tarihi: 30 Eylül 2020

Anahtar Kelimeler:

Çeviklik

Rekabet Gücü

Covid-19

Düzenleyici Etki

Aracı Etki

Yeni Ürün Geliştirme

\section{A R T ICLE INFO}

Article History:

Received August 30, 2020

Accepted September 30, 2020

\section{Keywords:}

Agility

Competitiveness

Covid-19

Moderating effect

Mediating effect

New Product Development

\begin{abstract}
Ö Z
Covid-19 salgını sürecinde dünya genelinde farklı rekabet şekilleri gözlemlenmektedir. Yeni ürünler geliştirip piyasaya sürebilmek, bu rekabet stratejilerinden birisidir. Covid-19 salgını ile de bazı sektörlerde yeni ürün geliştirmenin önemi ve aciliyeti ortaya çıkmıştır. Öte yandan, müşteri ve pazar taleplerine hızlı yanıt verebilmek için tedarik zincirinin de çevik olması gerekir. Bu durum şirketlere rekabet avantajı sağlayan diğer bir faktördür. Bu çalışmanın temel amacı, Covid-19 salgını sırasında firmaların rekabet gücü elde etmelerinde yeni ürün geliştirme ve tedarik zinciri çevikliğinin etkisi incelenmektedir. Ayrıca tedarik zinciri çevikliğinin rekabet gücü ve yeni ürün geliştirme ilişkisindeki düzenleyici ve aracılık rolünü ortaya koymaktır. Bu amaçlar doğrultusunda, çalışmada ilk olarak bu kavramlar teorik olarak tartışılmıştır. Veriler, önerilen modeli ve hipotezleri analiz etmek için anket aracılığıyla toplanmıştır. Araştırmanın evrenini Gaziantep sanayi bölgesinde faaliyet gösteren imalatçı firmalar oluşturmaktadır. Bootstrap yöntemine dayalı regresyon analizi yapılmış ve Process Macro kullanılarak analizler yapılmıştır. Analiz sonuçlarına göre Covid-19 pandemisi döneminde, yeni ürün geliştirmenin hem tedarik zinciri çevikliği hem de rekabet gücü üzerinde önemli pozitif etkiye sahip olduğu ortaya konmuştur. Ayrıca tedarik zinciri çevikliği rekabet gücünü pozitif yönde etkilemiştir. Çalışmanın bir diğer önemli konusu olan tedarik zinciri çevikliğinin, yeni ürün geliştirme ve rekabet gücü arasındaki ilişkide aracı ve düzenleyici rolünün tespitiyle ilgili analiz sonuçlarına göre ise aracı rolün bulunduğu ancak düzenleyici rolün olmadığı bulgulanmıştır.
\end{abstract}

\section{A B S T R A C T}

Different forms of competition are experienced during the Covid-19 pandemic period. Being able to develop and launch new products is one of the competitive strategies. With the Covid-19 outbreak, the importance and urgency of developing new products in some sectors have also emerged. On the other hand, the supply chain must be agile in order to respond quickly to customer and market demands. This is another factor that provides companies with competitive advantage. The main purpose of this study is to examine the effect of new product development and supply chain agility on firms' gaining competitiveness during the Covid-19 outbreak. It also reveals the moderator and mediating role of supply chain agility in the relationship between competitiveness and new product development. For these purposes, these concepts discussed theoretically in the study first. Data are collected through a survey to analyze the proposed model and hypotheses. Since the data are collected in the current epidemic period, the study is important in terms of revealing the importance given by firms to these three concepts in this period as well. The population of the study is composed of the manufacturing companies operating in the industrial zone of Gaziantep. Regression analysis based on the bootstrap method was conducted and analyzes were made by using Process Macro. According to the analysis results, it has been revealed that during the Covid-19 pandemic period, new product development has a significant positive effect on both supply chain agility and competitiveness. In addition, supply chain agility positively affected competitiveness. It was also found that supply chain agility has a mediating role in the relationship between new product development and competitiveness, but has no moderating effect in this relationship.

\footnotetext{
* Sorumlu yazar/Corresponding author.

e-posta: ahmet.cetindas@hku.edu.tr
} 


\section{EXTENDED ABSTRACT}

The Covid-19 epidemic, which emerged unexpectedly and affected the world, brought along economic uncertainties as in the consequences of globalization and caused change of competition conditions as well. The survival and success of companies in turbulent and uncertain environments as in this period is proportional to their competitive strategies. Competition can be defined as the struggle to be better among those who have the same or similar goal. Competitiveness refers to the power possessed to provide competitive advantage. Firm level competitiveness is being in a position equal or superior to its competitors in local, country or world markets in terms of factors such as low-cost production, quality of the product, service and attractiveness, and the ability to innovation and invent. From this point, new product development is a concept that includes the conceptualization, design, development and marketing steps of products and services that have not been on the market before. The aim of developing new products is to change the market conditions, meet consumer demands and needs, give a competitive position to the product or brand and increase its share in the market. Agility is also described as the capability of firms to react in terms of volume and diversity against unexpected and sudden changes in customer demand and markets. The importance of agility of supply chains was once again understood during the global Covid-19 pandemic. In this respect, the main purpose of this study is to determine the effect of new product development and supply chain agility on competitiveness during the Covid-19 pandemic. Afterwards, the moderating and mediating role of supply chain agility are examined. In addition, the effect of new product development on supply chain agility is also analyzed.

The population of the study composed of 534 manufacturing company operating in Gaziantep organized industrial zone. Returns from 534 surveys sent to be answered were 101 as total and 84 of these surveys could be evaluated. The hypotheses developed to be tested in the research are as follows:

H1: During the Covid-19 pandemic, new product development has a significant positive effect on supply chain agility.

H2: During the Covid-19 pandemic period, new product development has a significant positive effect on competitiveness.

H3: During the Covid-19 pandemic, supply chain agility has a significant positive effect on competitiveness.

H4: During the Covid-19 pandemic, the effect of new product development on competitiveness is mediated by supply chain agility.

H5: During the Covid-19 pandemic, supply chain agility has a moderating effect on the relationship between competitiveness and new product development.

In order to reveal the construct validity and reliability of the scales, exploratory factor analysis (EFA), reliability analysis and confirmatory factor analysis (CFA) were applied in the research. Values indicate the suitability of the sample size for factor analysis. Also, the detected Cronbach's Alpha values can be considered statistically reliable. The CFA results found that the scales fit well.

After EFA, CFA, and reliability analysis, the relationship between variables was determined by correlation analysis. According to the results of the correlation analysis, there are positive significant relationships between new product development and supply chain agility and competitiveness at the level of 0.01 significance. At this point, it can be stated that as the new product development levels of companies increase, their supply chain agility and competitiveness will increase. In addition, it is possible to say that there is a positive significant relationship between competitiveness and supply chain agility at a significance level of 0.01 .

In order to test the mediating role of supply chain agility in the effect of new product development on competitiveness, a regression analysis based on bootstrap method was conducted. Analyzes were made using Process Macro developed by Hayes (2018). According to the findings obtained as a result of the analysis, new product development positively affects the supply chain agility. New product development explains $32.93 \%(\mathrm{R} 2=.3293)$ of supply chain agility. Based on this, it is possible to say that the $\mathrm{H} 1$ hypothesis is accepted.

It has been determined that supply chain agility significantly affects competitiveness. New product development also significantly affects the competitiveness. Hence, the $\mathrm{H} 2$ and $\mathrm{H} 3$ hypotheses were approved. Supply chain agility and new product development explain $64.23 \%(\mathrm{R} 2=.6423)$ of the change on competitiveness.

According to the results of the mediation effect analysis of supply chain agility, it has been concluded that new product development has an indirect effect on competitiveness, thence supply chain agility mediates the relationship between new product development and competitiveness. Accordingly, the $\mathrm{H} 4$ hypothesis was accepted.

Multiple regression analysis was used to investigate the moderating effect of supply chain agility. Therefore, an interaction variable was created, which is the multiplication of the independent variable new product development and supply chain agility. Although both independent variables affect competitiveness, the interaction variable consisting of their multiplication does not affect competitiveness. Thus, it has been determined that supply chain agility has no moderating effect in this relationship. In other words, it has been determined that new product development and supply chain agility affect competitiveness, but supply chain agility does not have a moderating effect on this relationship. Therefore, the H5 hypothesis was rejected.

As a result of the research, the $\mathrm{H} 1, \mathrm{H} 2, \mathrm{H} 3$ and $\mathrm{H} 4$ hypotheses were supported, while the $\mathrm{H} 5$ hypothesis could not be supported. 


\section{Introduction}

Competition has existed in human life in various ways since the earliest times of history. Therefore, it has become an indispensable requirement for the continuity of people and societies to develop anti-competitive strategies and to gain competitive power against competitors. Changing conditions of competition are often due to developments in communication and transportation, which are the basis of globalization, and the reduction of trade barriers (Özgüner \& Özgüner, 2019:67). However, the Covid-19 epidemic, which emerged unexpectedly and affected the world, brought along economic uncertainties as in the consequences of globalization and caused change of competition conditions as well. The survival and success of companies in turbulent and uncertain atmospheres as in this period is proportional to their competitive strategies.

The Covid-19 outbreak, which occurred in Wuhan, China, started to spread around the world in March 2020 and subsequently declared as a pandemic by the World Health Organization. Due to the spread of the virus, restrictions on social and economic life have started in many countries. Due to the distance rules and lockdowns applied, serious changes in people' product and service demands who spend more time at their homes and product procurement processes of suppliers whom reduce their capacities have occurred. The world has started to demand different products and services that were not needed before the pandemic but specific to the pandemic period. The Covid-19 pandemic has also revealed strategic advantages and weaknesses in various sectors. Food, textile or hygiene producers, who can respond quickly in the face of increasing demand or offer alternative products for emerging needs, have turned the crisis environment which brought by the epidemic into an opportunity. Many new products and services such as disinfectant alternatives for crowded environments, apparatus to facilitate the use of masks, alternatives to travel restrictions, alternative channels to the education system have taken their place in the new world order. In addition, there has been an increase in electronic-based shopping, almost explosions have occurred in hygiene products, and the food sector has faced with the desire of consumers to stock beyond the needs. The survival of companies that cannot adapt to the changing world and changing market conditions due to the Covid-19 pandemic is very difficult in today's conditions. In addition to analyzing the market and the customer well, the availability of the production network and financial capabilities, the supply chain network also plays a very important role in this competitive race. It is essential to have a strong and integrated supply chain in order to introduce products and services of planned time, quantity and quality to the market. The efforts of companies to gain competitive power during the pandemic period should be supported by the potential to offer new products and services to the market and an agile supply chain. However, companies that cannot well managed their production capacities and strategies have failed in this global crisis.

The Covid-19 pandemic has once again shown that companies that can quickly adapt themselves to changes in consumer demands and needs, act innovative when necessary and become a pioneer in new products can successfully stand out in competitive environments. In this respect, the main purpose of this study is to state the effect of new product development and supply chain agility on competitiveness during the Covid-19 pandemic. Afterwards, the moderating and mediating role of supply chain agility will be examined. In addition, the effect of new product development on supply chain agility will also be analyzed. For the Covid literature, which contains mainly health-related studies, it is very necessary for both manufacturers and markets to conduct such a study on supply chains and production. Because the importance of the supply chains of all sectors, including the health sector, in reaching the final consumer was better understood during this crisis period. In this respect, the study is important in terms of revealing the effects of Covid-19 on production and supply chains and being a guide for producing enterprises. Since the data used in the analyzes were collected from 
companies that continued their production during the Covid period individually, the study is original and actual. It is possible to say that it is one of the first studies for the field, since there are not many studies that have collected and analyzed data in the relevant field in the Covid literature so far.

\section{Competitiveness}

Competition is a phenomenon that always maintains its presence in all areas of human life. However, different forms of competition are experienced during the Covid-19 pandemic period, where health is at the forefront. In this period, the first and the biggest competition emerged among the health practices of countries. In addition to the success of the applications, countries are in competition with each other in vaccine development studies. After health, the most competitive area is the production and consumption sectors, which are greatly affected by the mandatory quarantine and restriction practices of the countries. Both production and delivery disruptions and changes in consumer needs and demands have affected supply chains as well. Supply chain management, which is always important, has become even more important today due to the pandemic and has become an approach that businesses are closely interested in to increase their global competitiveness (Akben \& Güngör, 2018:2). Competitiveness is a multidimensional concept which purpose is to compose sustainable competitive superiority that is possible to apply at national, industry and company degree (Marín et al., 2012:366). It can also be described as the company's capability to design, manufacture or commercialize products that are higher compared to offered by others, taking into account the price and non-price quality of the firm (D'Cruz, 1992 cited in Maune, 2014:31). Competitiveness is a combination where properties are inherited (natural resources) or constituted (infrastructure) and procedures are turn out to generate economic gains (Maune, 2014:31). Organizing this combination, at least more successfully than competitors, gives companies competitive power.

Companies that reach international leadership in the world use different strategies in every respect. However, although every thriving firm implements its own specific strategy, the basic way of working is the same. Companies gain competitive advantage through innovation actions (Porter, 1990:75). Most of the leading companies in the sector can dominate the market since they have more innovative products and services than other companies (Altuğ, 2017:20). Innovative approaches, which are seen as one of the cornerstones of competition, are observed more clearly during the Covid-19 pandemic process. Many new products and services that were not needed in the pre-epidemic period have now taken their place among the essentials of daily life. Manufacturers who can respond to this new and rapid change of needs in the market have gained an important competition power.

However, Hart (2012) argued that inflexible processes, lack of communication, and difficult decision making in new product development will create difficulties for companies. He defined the formulas to cope with these difficulties as process flexibility, transparency, focusing and cooperation. It is obvious that a flexible and agile production line and supply chain are required to adapt quickly to new products. Ultimately, firms that can foresee and manage market, technical and competitive pressures are most likely to be successful in positioning new products (Ofek, 2008:81). During the pandemic process, it has become even more important for companies to successfully manage these difficulties. As a result, companies that analyze the needs and gaps of the market well and stand out with creative ideas have gained a great competitive power by taking advantage of the flexibility and agility of their supply chain processes as well.

\section{New Product Development}


New product development is a term that describes all stages of the procedure of introduce a product or service to market from nothing. The new product development process consists of two main ways: idea generation and product design, and market research and marketing analysis (Hart, 2012:2). The new product development process comprise the activities that companies apply while developing and launching new products. A new product launched on the market consists of a series of stages that are evaluated, tested and continued, starting with the idea of invention (Booz et al., 1982:11). Companies in many sectors affected by the Covid-19 pandemic process and expected to respond to different demands have once again understood the importance of new product development and made it a strategic agenda item. New product development is not only dependent on technological infrastructure and innovation. In addition to these, companies should develop new products according to the period of competition, environment and demand (Ofek, 2008:80). The Covid-19 pandemic period is also seen as a period when demands change, new products gain importance and competition rises.

According to the classification that Booz et al (1982:12) made and which is still valid today with some additions, the new product development stages are determined as follows:

- Idea Generation: This stage refers to the stage where new product ideas are searched systematically. Businesses generate hundreds or even thousands of ideas to come up with a handful of good ideas.

- Idea Screening: At this stage, product ideas that meet the company's goals are scanned. All generated ideas are scanned to identify the good ones and eliminate the weak ones as soon as possible.

- Concept Development and Testing: This stage consists of an early research to decide which ideas are appropriate and which ideas deserve further study. It is necessary to develop interesting ideas in the product concept to continue the new product development process.

- Marketing Strategy Development: After the development and testing stages for a promising idea, the initial marketing strategy is developed to launch the product.

- Business Analysis: At this stage, offerings are evaluated relying on quantitative elements such as profit, return on investment and sales capacity.

- Product Development: At this stage, ideas on paper are transformed into a demonstrable and producible product.

- Test Marketing: Commercial experiments are performed to verify previous operating decisions. The information obtained as a result of test marketing helps management to make the final decision to launch the new product.

- Commercialization: At this stage, products are released to the market. High costs can arise at this point: the company may have to set up or lease a production facility. Expenses for advertising, sales promotion and other marketing methods may be high in the first year.

The new product development activity series can also be seen as a series of information collection and assessment processes. Gathering information causes companies to improve their new product decisions by minimizing the resources associated with failed products (Booz et al., 1982:16). Especially during the pandemic period, collecting information from the market, understanding the changing preferences and demands and developing new products in the light of this information can increase competitiveness.

Despite extensive research on achieving success at new product development, companies are also developing products that are not accepted or not successful in the market. Therefore, new product development is among the most risky and complicated assignments for most 
companies. Companies face increased competition, stricter standardization and regulations, as well as changing customer behaviors and requirements during the Covid-19 pandemic (Berger, 2013:2). Under these factors, managing the new product development process requires extensive funding, human resources and time (Bhuiyan, 2011:747). Lockdowns implemented during the pandemic process, reduced capacities and uncertainties made it even more difficult to access these resources.

The NDP challenges and backgrounds determined by Berger (2013:5) can be explained as follows in terms of the pandemic period:

- Increasing global competition in all major markets: During the Covid-19 pandemic period, international companies that develop products according to demand offer them to the world.

- Shorter product life cycles: Since it is not known how long the pandemic will continue, it is uncertain how long the new products will be in demand.

- Higher failure rates in many industries: Error rates up to $60 \%$ of new products / inventions can be seen. This is a huge rate for businesses that have reduced their capacity due to the pandemic.

- Early cost detection: Some costs have also changed during the pandemic period. For instance, the price of nonwoven fabrics used in mask production has increased considerably due to high demand. Consumers' priority shifted to products with antivirus properties, which brought additional costs even to standard products.

From this point of view, the ability of the company to develop new products is also related to its competitiveness. While the product is launched, the existing products in the market should be investigated and features that are better than the competitor's product should be identified. Basically, competitors and their products can be an important source of information for new product launches. In addition to creating new, technologically improved solutions, manufacturers must have the capability to create a competitive product proposal (Kazimierska \& Grębosz-Krawczyk, 2017:249).

\section{Supply Chain Agility}

In the modern competitive environment, instead of "firm versus firm", "supply chain versus supply chain" is struggling (Ketchen \& Giunipero, 2004:55). Within the supply chain, the trust of companies to each other will increase cooperation and higher performance will occur with less opportunism (Ekinci \& Y1ldız, 2017:65). Supply chain agility, which is the result of collaboration, allows a company to respond rapidly and effectively to market mobility and other instability, enabling the company to set up a upper competitive position (Swafford et al., 2008). The Covid-19 pandemic process has caused many uncertainties in terms of both demand and supply. Therefore, companies need to plan their supply chains more flexible and more agile. Supply chain agility is a criteria of how quickly the supply chain is able to react (Swafford et al., 2006:171).

An agile supply chain responds to dynamic market conditions with the following four abilities (Arteta \& Giachetti, 2004:496; Agarwal et al., 2007:443; Gong \& Janssen, 2012; Yusuf et al., 2014). These abilities are interpreted according to the Covid-19 pandemic period as follows:

- Flexibility: The ability to quickly reforge resources and processes to meet changing customer demands during the pandemic period.

- Sensitivity: The ability to anticipate uncertainty caused by the pandemic and respond earlier than competitors.

- Speediness: The ability to execute an activity in the shortest possible time frame. 
- Competence: The ability to continue flow in the supply chain.

\section{Literature Review and Development of Research Hypotheses}

\section{Relationship between New Product Development and Supply Chain Agility}

In today's dynamic business atmosphere, companies that have the ability to produce and develop new products and services faster and at a lower cost achieve success in the sector (Hart, 2012). New product development process may take a long time. This may mean that companies cannot offer new products or services to the market when required. The increasing intensity of competition in the market considers the timing factor as an important criterion in developing and introducing new products (Altuğ, 2017:27). Meeting the needs and requirements of the customers, providing the required product type and volume on time, and launching new products quickly are considered as competitive priorities of the supply chain (Carvalho et al., 2012:55). The goal of the agile supply chain is to launch personalized new products with matchless characters to the market in order to keep competitive advantage in today's changing atmosphere (Ambe, 2010:12). As seen during the pandemic period, an agile supply chain is required to respond to the variable customer demand and the need for high diversity (Agarwal et al., 2007).

Importance of having an agile supply chain in the companies' new product development strategies have seen from the studies in the literature. Considering that companies can respond to changes in the market faster thanks to the new products they produce during the pandemic period and thus they are in a more agile supply chain, the first hypothesis of the study was developed as follows:

H1: During the Covid-19 pandemic, new product development has a significant positive effect on supply chain agility.

\section{Relationship Between New Product Development and Competitiveness}

New product development underlines the value of presentation new products to the market in order to maintain business success (Bhuiyan, 2011:747). The new product development process is important for the creation of products that meet the requirements of industrial customers and diversify the firm among the competition (Kazimierska \& GręboszKrawczyk, 2017). Innovation can occur in the form of a new product design, a new manufacturing process, a fresh marketing perspective, or a new form of training. Some innovations build up a competitive advantage by understanding a completely new market opportunity or by offering a market section that others ignore (Porter, 1990:75).

Craig and Hart (1992) revealed in their study on the evaluation of new product development process that the concepts of market competition and technology competition effect performance. Customer demands and needs, technology and competition are constantly changing and developing. In this case, companies need to develop new products or services in order to survive and compete in the sector (Altuğ, 2017:20). Similarly, Yiğit (2017:50) stated that companies must be able to produce new products in order to survive in competitive environments.

Companies that can offer new and different products to the market at the proper period and before other companies will gain competitive advantage due to the changing needs of the Covid-19 pandemic. Based on previous studies, it is possible to say that the ability of companies to develop new products has an important role in their competitive power. It will be an expected result for companies that differentiate from their competitors in the market with new products and meet the changing customer needs faster and more efficiently during the Covid-19 pandemic. The second hypothesis of the study was developed in this direction as follows: 
H2: During the Covid-19 pandemic period, new product development has a significant positive effect on competitiveness.

\section{Relationship between Supply Chain Agility and Competitiveness}

Supply chain agility directly increases the competitive performance of the firm (Swafford et al., 2008). Supply chain agility is a trait that is counted as a strategic source to support a company gain a competitive advantage (Ivanov, 2010:2; Stratton \& Warburton, 2006:677). Competitors slow reactions to changes in demand and market provides competitive advantage to firm (Porter, 1990:75). It is obvious that the agile supply chain is an important strategy for competitive advantage (Ambe, 2010:13).

Goldman et al. (1995) describe an agile organization as having the ability to gain a dynamic and competitive advantage. Wu et al. (2017:25) revealed that there is a positive relationship between an agile supply chain and competitive advantage. Um (2017:15) found the effect of supply chain agility on both customer service and differentiation from competitors.

Agility becomes an even more important source of competitiveness in turbulent business environments (Maune, 2014:31). Studies have shown that an agile supply chain provides companies with competitive advantage. During the Covid-19 pandemic, it is undeniable that an agile supply chain is necessary to respond to changes in the market and demand before competitors. As a result of supply chains that cannot keep up with the changes, staying behind the competitive environment in the market will be an expected result. In the light of these information, the next hypothesis of the study was formed as follows:

H3: During the Covid-19 pandemic, supply chain agility has a significant positive effect on competitiveness.

\section{Moderating and Mediating Role of Supply Chain Agility}

There have been many studies in the literature on the moderating and mediating role of supply chain agility in different relationships. Dhaigude and Kapoor stated that supply chain agility acts as a mediating between supply chain orientation and supply chain performance (Dhaigude \& Kapoor, 2017:287). Swafford et al. stated that the mediating role of supply chain agility creates an indirect relationship between integration and performance in their studies where they reveal the relationship between flexibility, agility and information technology (Swafford et al., 2006:170). Yıldız and Çetindaş (2018:892) found that supply chain agility has a partial mediating role in the relationship between strategic resource use and firm performance. In a different study, the authors revealed that supply chain agility has a mediating role in the effect of supply chain integration on firm performance (Yıldız \& Çetindaş, 2020:195). Khan and Wisner (2019:19) revealed that supply chain agility mediates the relationships between supply chain integration, external learning and internal learning and firm performance. Also, in the same study, the mediating role of supply chain agility in the effect of supply chain integration on firm performance was also determined. Liu et al. (2013:1459) stated that supply chain agility fully mediates the effect of both flexible information technology substructure and information technology assimilation on firm performance. Betts and Tadisina (2009:14) examined the moderating effect of supply chain agility in the relationship between supply chain collaboration and supply chain performance in their studies.

As can be understood from the studies in the literature, supply chain agility is likely to have a moderating and mediating effect on the relationship between new product development and competitiveness in uncertain environments such as in the pandemic. Therefore, the last two hypotheses of the study were formed as follows: 
H4: During the Covid-19 pandemic, the effect of new product development on competitiveness is mediated by supply chain agility.

H5: During the Covid-19 pandemic, supply chain agility has a moderating effect on the relationship between competitiveness and new product development.

\section{Model and Methodology}

The main purpose of this study is to examine the impact of new product development and supply chain agility on firm competitiveness during the Covid-19 pandemic and the moderating and mediating role of supply chain agility in this effect. The impact of new product development on supply chain agility is also analyzed. The hypotheses developed to be tested in the research are as follows:

H1: During the Covid-19 pandemic, new product development has a significant positive effect on supply chain agility.

H2: During the Covid-19 pandemic period, new product development has a significant positive effect on competitiveness.

H3: During the Covid-19 pandemic, supply chain agility has a significant positive effect on competitiveness.

H4: During the Covid-19 pandemic, the effect of new product development on competitiveness is mediated by supply chain agility.

H5: During the Covid-19 pandemic, supply chain agility has a moderating effect on the relationship between competitiveness and new product development.

Figure 1. shows the research model:

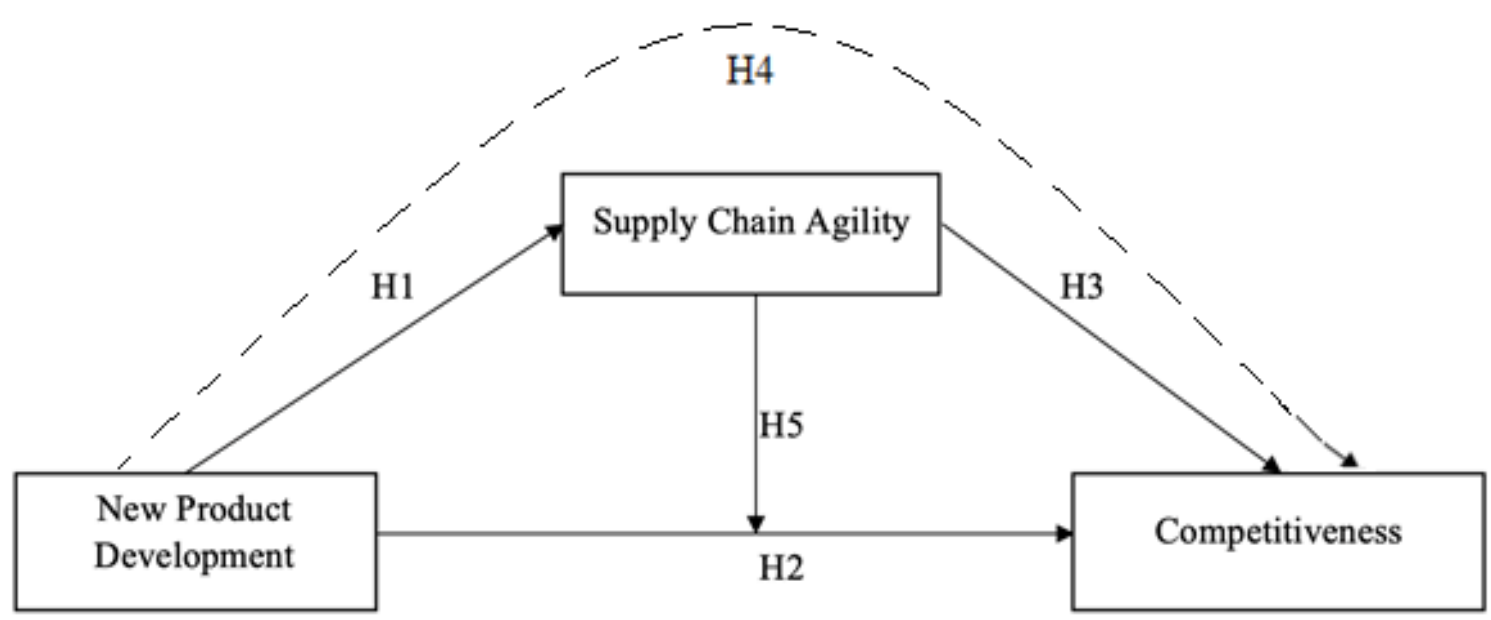

Figure 1: Research Model

Data are collected through a survey to analyze the proposed model and hypotheses. Since the data are collected in the current epidemic period, the study is important in terms of revealing the importance given by firms to these three concepts in this period as well. The population of the study composed of 534 manufacturing company operating in Gaziantep organized industrial zone. Returns from 534 surveys sent to be answered were 101 as total and 84 of these surveys could be evaluated. Due to the Covid-19 pandemic, financial problems experienced by companies, lockdowns and employees working from home to protect social distance have made the data collection process difficult. In addition, the fact that employees in 
the companies continuing production have an uneasy and nervous mood due to the pandemic caused them to behave timidly at the point of answering the survey. However, it was thought that the 84 data obtained would be sufficient for the analysis to be made. The competitiveness scale used in the study is based on Yön (2007), the supply chain agility scale is based on Um et al. (2017) and the new product development scale was adapted from Yildirmaz (2008). A 5point Likert Scale was used in all scales. Participants' degree of agreement with the statements is interpreted in the range of $1=$ Strongly Disagree, $5=$ Strongly Agree. In order to reveal the construct validity and reliability of the scales, exploratory factor analysis (EFA), reliability analysis and confirmatory factor analysis (CFA) were applied in the research.

EFA and reliability analysis results of the new product development scale are given in Table 1.

Table 1: New Product Development Factor Loadings and Reliability Analysis

\begin{tabular}{|c|c|c|c|c|}
\hline Items & $\begin{array}{l}\text { Factor } \\
\text { Loadings }\end{array}$ & Alpha & KMO & $\begin{array}{l}\text { Tot. Exp. } \\
\text { Var. (\%) }\end{array}$ \\
\hline NPD3: New product development speed & 833 & \multirow{9}{*}{0,893} & \multirow{9}{*}{0,862} & \multirow{9}{*}{54,292} \\
\hline NPD2: Being able to launch new products before competitors & ,795 & & & \\
\hline NPD5: Sales of newly developed products & ,784 & & & \\
\hline NPD7: New product development flexibility & ,781 & & & \\
\hline NPD6: Profitability of newly developed products & ,756 & & & \\
\hline NPD8: New product development quality & ,700 & & & \\
\hline NPD4: New product development cost & ,683 & & & \\
\hline NPD1: Quality of newly developed products & 647 & & & \\
\hline $\begin{array}{l}\text { NPD9: Lessons learned in the new product development } \\
\text { process }\end{array}$ & ,624 & & & \\
\hline
\end{tabular}

AVE: 0,54 CR: 0,91

As seen in Table 1, the factor loadings of the new product development scale are in the range of 0.624 to 0.833 . The KMO value was determined as 0.862 and was obtained as $\mathrm{p}<0.01$. These values indicate the fitness of the sample size for factor analysis. It is seen that the scale explains $54.292 \%$ of the total variance and the alpha coefficient is found as 0.893 as a result of the reliability analysis. The detected Cronbach's Alpha value can be considered statistically reliable (Baş, 2008:147).

EFA and reliability analysis results of the competitiveness scale are given in Table 2.

Table 2: Competitiveness Factor Loadings and Reliability Analysis

\begin{tabular}{|c|c|c|c|c|}
\hline Items & $\begin{array}{l}\text { Factor } \\
\text { Loadings }\end{array}$ & Alpha & KMO & $\begin{array}{l}\text { Tot. Exp. } \\
\text { Var. (\%) }\end{array}$ \\
\hline $\begin{array}{l}\text { C4: Our company compared to our competitors in terms of } \\
\text { market share ... }\end{array}$ & ,859 & \multirow{5}{*}{0,872} & \multirow{5}{*}{0,839} & \multirow{5}{*}{62,141} \\
\hline $\begin{array}{l}\text { C1: Our company compared to our competitors in terms of } \\
\text { customer satisfaction ... }\end{array}$ & ,812 & & & \\
\hline $\begin{array}{l}\text { C3: Our company compared to our competitors in terms of } \\
\text { quality ... }\end{array}$ & ,800 & & & \\
\hline $\begin{array}{l}\text { C5: Our company compared to our competitors in terms of } \\
\text { new product development ... }\end{array}$ & ,787 & & & \\
\hline $\begin{array}{l}\text { C6: Our company compared to our competitors in terms of } \\
\text { profitability ... }\end{array}$ & ,786 & & & \\
\hline
\end{tabular}


C2: Our company compared to our competitors in terms of price / cost advantage...

, 674

AVE: 0,62, CR: 0,90

As indicated in Table 2, the factor loadings of the competitiveness scale as a result of EFA were determined between 0.674 and 0.859 . The KMO value is 0.839 and it was found as $\mathrm{p}<0.01$. According to the findings, the sample size is suitable for factor analysis. It is seen that the scale explains $62.141 \%$ of the total variance and the alpha coefficient is found as 0.839 as a result of the reliability analysis. It is possible to say that the Cronbach's Alpha value of the competitiveness scale is statistically reliable (Baş, 2008:147).

EFA and reliability analysis results of the supply chain agility scale are given in Table 3.

Table 3: Supply Chain Agility Factor Loadings and Reliability Analysis

\begin{tabular}{|c|c|c|c|c|}
\hline Items & $\begin{array}{l}\text { Factor } \\
\text { Loadings }\end{array}$ & Alpha & KMO & $\begin{array}{l}\text { Tot. Exp. } \\
\text { Var. }(\%)\end{array}$ \\
\hline $\begin{array}{l}\text { SCA5: Our ability to rapidly improve delivery reliability } \\
\text { compared to our competitors... }\end{array}$ & ,887 & \multirow{7}{*}{0,921} & \multirow{7}{*}{0,905} & \multirow{7}{*}{68,569} \\
\hline $\begin{array}{l}\text { SCA3: Our ability to rapidly increase the level of product } \\
\text { customization compared to our competitors... }\end{array}$ & ,883 & & & \\
\hline $\begin{array}{l}\text { SCA2: Our ability to rapidly reduce lead time compared to our } \\
\text { competitors ... }\end{array}$ & ,838 & & & \\
\hline $\begin{array}{l}\text { SCA7: Our ability to rapidly reduce delivery lead time } \\
\text { compared to our competitors ... }\end{array}$ & ,832 & & & \\
\hline $\begin{array}{l}\text { SCA4: Our ability to rapidly improve the level of customer } \\
\text { service compared to our competitors ... }\end{array}$ & ,824 & & & \\
\hline $\begin{array}{l}\text { SCA6: Our ability to rapidly increase our ability to } \\
\text { responsiveness to changing market needs compared to our } \\
\text { competitors... }\end{array}$ & ,772 & & & \\
\hline $\begin{array}{l}\text { SCA1: Our ability to rapidly reduce the product development } \\
\text { cycle time compared to our competitors ... }\end{array}$ &, 751 & & & \\
\hline
\end{tabular}

AVE: 0,68, CR: 0,94

In Table 3, it is seen that the factor loadings of the competitiveness scale are between 0.751 and 0.887 . The KMO value was found as 0.905 and was obtained as $\mathrm{p}<0.01$. Similarly, this finding reveals that the sample size is suitable for factor analysis. It has been determined that the scale explains $68,569 \%$ of the total variance. As a result of the reliability analysis, the alpha coefficient was found as 0.921 , and this Cronbach's Alpha value is also a statistically reliable value (Baş, 2008:147).

For all scales, the AVE value was obtained over 0.5 and the CR value over 0.7 . In addition, the CR> AVE condition is provided. After analyzing the factor loadings and reliability of the scales, a confirmatory factor analysis (CFA) was conducted to see that they ensure structural validity. Table 4 shows the goodness of fit values achieved for the scales as a result of CFA.

Table 4: CFA Goodness of Fit Values

\begin{tabular}{c|c|c|c|c|c|c|c}
\hline Variable & CMIN & DF & CMIN/DF & GFI & CFI & TLI & RMSEA \\
\hline $\begin{array}{c}\text { New Product } \\
\text { Development }\end{array}$ & 23,343 & 20 & 1,167 & 0,942 & 0,991 & 0,984 & 0,045 \\
\hline Competitiveness & 9,882 & 7 & 0,412 & 0,966 & 0,988 & 0,974 & 0,07 \\
\hline Supply Chain Agility & 15,893 & 13 & 1,223 & 0,950 & 0,993 & 0,988 & 0,052 \\
\hline
\end{tabular}

The CFA result found that the scales fit well. 
After EFA, CFA, and reliability analysis, the relationship between variables was determined by correlation analysis. Correlation analysis findings are given in Table 5.

Table 5: Correlation Analysis

\begin{tabular}{c|c|c|c|c|c}
\hline & Mean & $\begin{array}{c}\text { Std. } \\
\text { Deviation }\end{array}$ & $\begin{array}{c}\text { New Product } \\
\text { Development }\end{array}$ & $\begin{array}{c}\text { Supply Chain } \\
\text { Agility }\end{array}$ & Competitiveness \\
\hline $\begin{array}{c}\text { New Product } \\
\text { Development }\end{array}$ & 3,8801 &, 60583 & 1 & & \\
\hline $\begin{array}{c}\text { Supply Chain } \\
\text { Agility }\end{array}$ & 4,0204 &, 65264 &, $574^{* *}$ & 1 & \\
\hline Competitiveness & 3,8837 &, 66764 &, $635^{* *}$ &, $765^{* *}$ & 1 \\
\hline
\end{tabular}

According to the results of the correlation analysis, there are positive significant relationships between new product development and supply chain agility $(r=574)$ and competitiveness $(r=, 635)$ at the level of 0.01 significance. At this point, it can be stated that as the new product development levels of companies increase, their supply chain agility and competitiveness will increase. In addition, as seen in Table 5, the correlation coefficient between competitiveness and supply chain agility was determined as $r=.765$. From this point of view, it is possible to say that there is a positive significant relationship between competitiveness and supply chain agility at a significance level of 0.01 .

Table 6: Normal Distribution Table

\begin{tabular}{c|c|c|c|c}
\hline \multicolumn{2}{c|}{} & $\begin{array}{c}\text { New Product } \\
\text { Development }\end{array}$ & $\begin{array}{c}\text { Supply Chain } \\
\text { Agility }\end{array}$ & Competitiveness \\
\hline $\mathbf{N}$ & Valid & 84 & 84 & 84 \\
\hline 84 & Missing & 0 & 0 & 0 \\
\hline \multicolumn{2}{r|}{ Skewness } &,- 392 &,- 580 &,- 710 \\
\hline \multicolumn{2}{r|}{ Skewness's Standard Error } &, 263 &, 263 &, 263 \\
\hline \multicolumn{2}{r|}{ Kurtosis's Standard Error } &, 812 &, 836 & 1,143 \\
\hline
\end{tabular}

As seen in Table 6, the skewness values of the distribution were determined respectively as new product development -.392 , supply chain agility -.580 , competitiveness -.710 . The kurtosis values of the distribution are respectively found as new product development ,812, supply chain agility ,836, and competitiveness as 1.143 . These values between -2 and +2 indicate that the distribution is normal at an acceptable level (George \& Mallery, 2013). The normal distribution ensures that the results of the analysis to be made are correct.

In order to test the mediating role of supply chain agility in the effect of new product development on competitiveness, a regression analysis based on bootstrap method was conducted. Analyzes were made using Process Macro developed by Hayes (2018). Analysis results are given in Table 7.

Table 7: Mediation Test's Regression Analysis Results

\begin{tabular}{l|l|l|l}
\hline \multicolumn{3}{|c}{ Result Variables } \\
\hline & M (Supply Chain Agility) & & Y (Competitiveness) \\
\hline
\end{tabular}




\begin{tabular}{|c|c|c|c|c|c|c|}
\hline $\begin{array}{l}\text { Predictor } \\
\text { Variable }\end{array}$ & & $\mathrm{b}$ & S.E. & & $\mathrm{b}$ & S.E. \\
\hline $\begin{array}{l}\text { X (New Product } \\
\text { Development) }\end{array}$ & $\mathrm{a}$ & $.6181 * * *$ & .0974 & $\mathrm{c}^{\prime}$ & $.3231 * * *$ & .0994 \\
\hline $\begin{array}{c}\text { M (Supply } \\
\text { Chain Agility) } \\
\end{array}$ & - & - & - & $\mathrm{b}$ & $.610 * * *$ & .0830 \\
\hline \multirow[t]{3}{*}{ Constant } & IM & $1.6219 * * *$ & .3826 & IY & $0.1773 * * *$ & .3175 \\
\hline & & \multicolumn{2}{|c|}{$\mathrm{R} 2=.3293$} & & \multicolumn{2}{|c|}{$\mathrm{R} 2=.6423$} \\
\hline & \multicolumn{2}{|c|}{$\mathrm{F}(1 ; 82)=40,2530 ; \mathrm{P}<.001$} & & \multicolumn{3}{|c|}{$F(2 ; 81)=72,7138 ; P<.001$} \\
\hline
\end{tabular}

$* * * \mathrm{p}<.001$

According to the findings obtained as a result of the analysis, new product development positively affects the supply chain agility (B: $0.6181, \% 95$ CI [.4243, .8120], t: 6,3445, p<.001). The Beta value obtained is considered significant since both the p value is less than .001 and the values belonging to the confidence interval have the same directional sign (+/-). New product development explains $32.93 \%(\mathrm{R} 2=.3293)$ of supply chain agility. Based on this, it is possible to say that the $\mathrm{H} 1$ hypothesis is accepted.

It has been determined that supply chain agility significantly affects competitiveness (B: $0.610, \% 95$ CI [.4449, .7752], t: 7,3491, p<.001). New product development also significantly affects the competitiveness (B:.3231, \%95 CI [.1452, .5011], t: 3,6136, p<.001). Beta value is considered as meaningful because both the $\mathrm{p}$ value is less than .001 and the values of the confidence interval have the same directional sign (+/-). Hence, the H2 and H3 hypotheses were approved. Supply chain agility and new product development explain $64.23 \%$ (R2 $=.6423$ ) of the change on competitiveness.

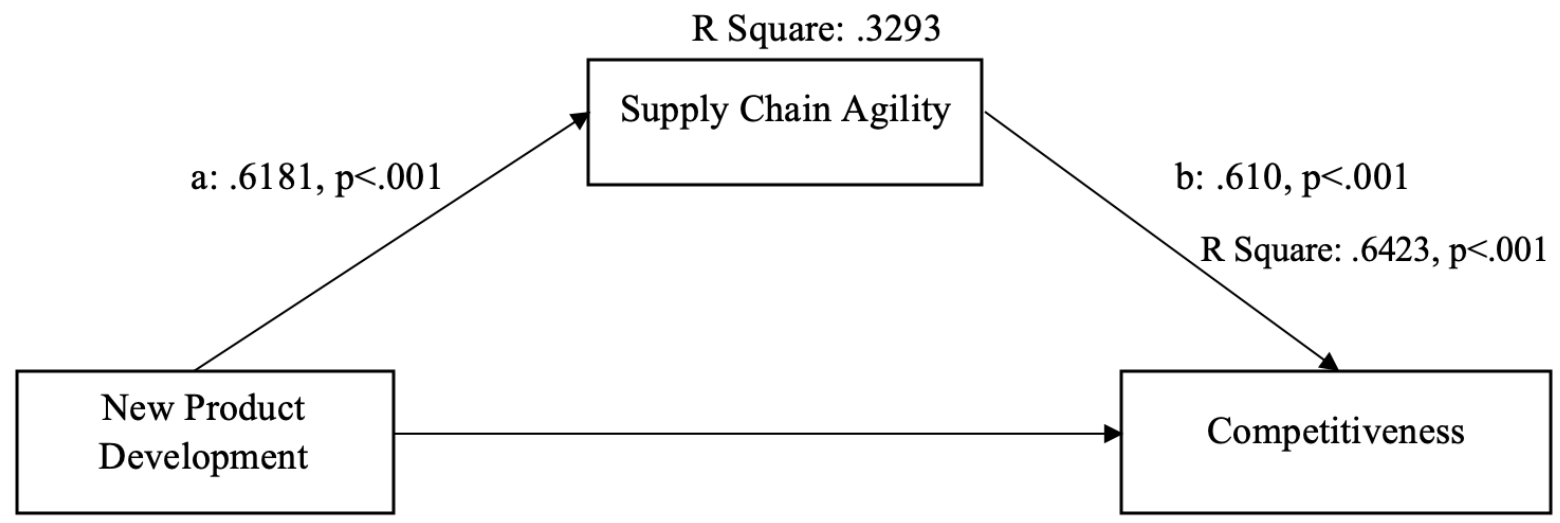

Direct Effect (c'): .3231, p $<.001$

Indirect Effect: B: .3771, \%95 CI [.2165, .5587]

Figure 2: Mediation Effect Analysis

In Figure 2, the results of the mediation effect analysis of supply chain agility are given. It has been concluded that new product development has an indirect effect on competitiveness, thence supply chain agility mediates the relationship between new product development and competitiveness. (B: .3771, \%95 CI [.2165, .5587], p<.001). Accordingly, the H4 hypothesis was accepted.

Multiple regression analysis was used to investigate the moderating effect of supply chain agility. Therefore, an interaction variable was created, which is the multiplication of the independent variable new product development and SCA. In order to talk about the moderating effect, new product development and supply chain agility should have an effect on 
competitiveness as well as the newly created interaction variable. Analysis results are as in Table 8.

Table 8: Moderating Effect Analysis Results

\begin{tabular}{c|c|c|c|c|c}
\hline \multirow{2}{*}{$\begin{array}{c}\text { Independent } \\
\text { Variables }\end{array}$} & \multicolumn{5}{|c}{$\begin{array}{c}\text { Dependent variable } \\
\text { Competitiveness }\end{array}$} \\
\cline { 2 - 6 } & $\boldsymbol{\beta}$ & Std. Error & Beta & t- Value & p- Value \\
\hline $\begin{array}{c}\text { New Product } \\
\text { Development }\end{array}$ &, 187 & .056 & .279 & 3,351 & .001 \\
\hline $\begin{array}{c}\text { Supply Chain } \\
\text { Agility }\end{array}$ &, 392 & .055 & .588 & 7,155 & .000 \\
\hline NPD*SCA &,- 025 & .033 & -.054 &,- 751 & .455 \\
\hline
\end{tabular}

As seen in Table 8, although both independent variables affect competitiveness, the interaction variable consisting of their multiplication does not affect competitiveness. Thus, it has been determined that supply chain agility has no moderating effect in this relationship. In other words, it has been determined that new product development and supply chain agility affect competitiveness, but supply chain agility does not have a moderating effect on this relationship. Therefore, the H5 hypothesis was rejected.

\section{Conclusion}

With the Covid-19 pandemic that shook the world since December 2019, the importance of both new product development and supply chain agility was once again understood. Consumer needs and habits have changed very rapidly due to the pandemic affecting almost every sector, especially health, worldwide. Due to the manufacturers who cannot respond to these sudden changes in consumption with the same speed, supply problems have been experienced in many parts of the world in masks, paper products, disinfectants and dry foods. Precisely in these market conditions, both the leading companies that can offer new products and services to the market and the producers benefiting from the agility of their supply chains have quickly filled the supply gap in the market and gained an undeniable competitive power.

The purpose of this study, which was conducted after the effects of the Covid-19 pandemic began to emerge, is to reveal the relationship between the supply chain agility and competitiveness of companies that develop new products during Covid-19 pandemic. At the same time, the mediating and moderating role of supply chain agility in this relationship is examined. In this respect, firstly, the concepts are discussed theoretically and studies that have investigated similar relations in the literature are examined. Based on the studies in the literature, 5 hypotheses were developed. With the first hypothesis, the effect of new product development on supply chain agility during the Covid-19 pandemic process was analyzed, and it was found that the companies developing new products have a more agile supply chain, and H1 was accepted. In addition, by proving the significant positive effect of new product development on competitiveness during covid-19 pandemic, H2 was also accepted. In the current global epidemic, it has been understood that one of the important ways to differentiate from competitors beyond the borders of the country and get ahead is to develop new products.

In the third hypothesis of the study, the effect of supply chain agility on competitiveness is examined. As a result of the analysis, it was found that supply chain agility has a positive and significant effect on competitiveness in accordance with the literature, and thus H3 was accepted. It is essential to have an agile supply chain in order to respond quickly to the sudden 
changes in the market due to the global epidemic and to the differentiation of customer demands and expectations. The ability of production, sales and distribution personnel, starting with the suppliers, to adapt to this change in the fastest way will bring the company forward in the race against its competitors.

The fourth hypothesis of the research is the mediating role of supply chain agility in the effect of new product development on competitiveness. As a result of the analysis conducted based on the studies examining the mediation effect of supply chain agility in the literature, the mediating role of supply chain agility in the effect of new product development on competitiveness was proven and $\mathrm{H} 4$ was accepted. Finally, the moderating role of supply chain agility in the effect of new product development on competitiveness is analyzed. However, as a result of the analysis, it was found that supply chain agility does not have a moderating role in this relationship. In other words, it is possible to say that there is no moderating role when talking about the intermediary role of the supply chain. Hence, it was understood that supply chain agility had no moderating role in the effect of new product development on competitiveness and H5 was rejected.

As a result of the literature review and analyzes, companies that develop new products have positive effects on the competitiveness and supply chain agility, therefore, the fact that new product development increases their competitiveness and supply chain agility has been revealed once again. In addition, it is a fact that supply chain agility provides companies competitive power. Since the data used in the study were collected during the Covid-19 pandemic period, the findings cover this period. The continuous state of uncertainty is also a sign that companies may face new competition situations in supply and demand conditions. Therefore, in order not to lose their competitiveness, companies are recommended to read customer needs well and market dynamics, develop new products according to their needs and plan their supply chains more agile in order to adjust to unexpected changes. Since this study is one of the first studies for the relevant field in the Covid literature, it is possible to say that the study will shed light on future studies. In order to further the study, researchers are recommended to re-investigate other researched strategies related to supply chain management during the pandemic period.

\section{References}

Agarwal, A., Shankar, R., \& Tiwari, M. K. (2007). Modeling agility of supply chain. Industrial Marketing Management, 36(4), 443-457.

Akben, İ., \& Güngör, A. (2018). Tedarik zinciri ve yalın tedarik zinciri. Avrasya Sosyal ve Ekonomi Araştırmaları Dergisi, 5(7), 1-12.

Altuğ, N. (2017). İşletmelerde yeni ürün geliştirme çalışmaları ve başarı faktörleri. Balkan ve Yakın Doğu Sosyal Bilimler Dergisi, 03(02), 20-28.

Ambe, I. M. (2010). Agile supply chain: strategy for competitive advantage. Journal of Global Strategic Management, 1(4), 5-5.

Arteta, B. M., \& Giachetti, R. E. (2004). A measure of agility as the complexity of the enterprise system. Robotics and Computer-Integrated Manufacturing, 20 (6 SPEC. ISS.), 495-503.

Baş, T. (2008). Anket: anket nasıl hazırlanır, uygulanır, değerlendirilir? (5. Edition). Seçkin Yayıncilik.

Berger, R. (2013). Best practices in new product development. Brandenburgische Technische Universitat, April, 1-21.

https://www.rolandberger.com/media/pdf/Roland_Berger_Best_practices_in_new_produ ct_development_20130419.pdf 
Betts, T., \& Tadisina, S. K. (2009). Supply chain agility, collaboration, and performance: how do they relate? POMS 20th Annual Conference, 1-22.

Bhuiyan, N. (2011). A framework for successful new product development. Journal of Industrial Engineering and Management, 4(4), 746-770.

Booz, Allen, \& Hamilton. (1982). New product management for the 1980s (pp. 11-18). Jones \& Bartlett Learning, LLC.

Carvalho, H., Azevedo, S. G., \& Cruz-Machado, V. (2012). Agile and resilient approaches to supply chain management: Influence on performance and competitiveness. Logistics Research, 4(1-2), 49-62.

Christopher, M. (2000). The agile supply chain: competing in volatile markets. Industrial Marketing Management, 29(1), 37-44.

Craig, A., \& Hart, S. (1992). Where to now in new product development research? European Journal of Marketing, 26(11), 2-49.

Dhaigude, A., \& Kapoor, R. (2017). The mediation role of supply chain agility on supply chain orientation-supply chain performance link. Journal of Decision Systems, 26(3), 275-293.

Ekinci, G., \& Yıldız, B. (2017). 3. PL'de Taraflar Arasında Fırsatçılığa Etki Eden Faktörler. In Z. NAŞ \& V. Şönmez (Eds.), 1. Uluslararası El-Ruha Sosyal Bilimler Kongresi (p. 65). İksad Yayınevi.

George, D., \& Mallery, P. (2013). IBM SPSS statistics 19 step by step a simple guide and reference (Pearson (ed.); 13. Editio).

Goldman, S. L., Nagel, R. N., \& Preiss, K. (1995). Agile competitors and virtual organizations: strategies for enriching the customer. Van Nostrand Reinhold.

Gong, Y., \& Janssen, M. (2012). From policy implementation to business process management: Principles for creating flexibility and agility. Government Information Quarterly, 29(SUPPL. 1), 61-71.

Hart, S. (2012). Important facts about new product development. The Marketing Book, July, 314-341.

Hayes, A. f. (2018). Introduction to mediation, moderation, and conditional process analysisA regression based approach (Told D. Little (ed.); Second Edi). The Guilford Press.

Ivanov, D. (2010). An adaptive framework for aligning (re)planning decisions on supply chain strategy, design, tactics, and operations. International Journal of Production Research, 48(13), 3999-4017.

Kazimierska, M., \& Grębosz-Krawczyk, M. (2017). New product development (npd) process - an example of industrial sector. Management Systems in Production Engineering, 25(4), 246-250.

Ketchen, D. J., \& Giunipero, L. C. (2004). The intersection of strategic management and supply chain management. Industrial Marketing Management, 33(1), 51-56.

Khan, H., \& Wisner, J. D. (2019). Supply chain integration, learning, and agility: Effects on performance. Operations and Supply Chain Management, 12(1), 14-23.

Liu, H., Ke, W., Wei, K. K., \& Hua, Z. (2013). The impact of IT capabilities on firm performance: The mediating roles of absorptive capacity and supply chain agility. Decision Support Systems, 54(3), 1452-1462. 
Marín, L., Rubio, A., \& de Maya, S. R. (2012). Competitiveness as a atrategic outcome of corporate social responsibility. Corporate Social Responsibility and Environmental Management, 19(6), 364-376.

Maune, A. (2014). Competitive intelligence as an enabler for firm competitiveness: an overview. Journal of Governance and Regulation, 3(2), 29-42.

Ofek, E. (2008). Competitive positioning through new product development. In C. H. Loch \& S. Kavadias (Eds.), Handbook of New Product Development Management (1st ed., pp. 49-86). Elsevier.

Özgüner, M., \& Özgüner, Z. (2019). Tedarik zinciri riskleri’nin lojistik performans üzerindeki etkisinin yapısal eşitlik modellemesi ile belirlenmesi. Eskişehir Osmangazi Üniversitesi IIBF Dergisi, 14(1), 67-82.

Porter, M. E. (1990). The competitive advantage of nations. Harvard Business Review.

Qrunfleh, S., \& Tarafdar, M. (2013). Lean and agile supply chain strategies and supply chain responsiveness: the role of strategic supplier partnership and postponement. Supply Chain Management, 18(6), 571-582.

Stratton, R., \& Warburton, R. D. H. (2006). Managing the trade-off implications of global supply. International Journal of Production Economics, 103(2), 667-679.

Swafford, P. M., Ghosh, S., \& Murthy, N. (2006). The antecedents of supply chain agility of a firm: Scale development and model testing. Journal of Operations Management, 24(2), $170-188$.

Swafford, P. M., Ghosh, S., \& Murthy, N. (2008). Achieving supply chain agility through IT integration and flexibility. International Journal of Production Economics, 116(2), 288297.

Um, J. (2017). The impact of supply chain agility on business performance in a high level customization environment. Operations Management Research, 10(1-2), 10-19.

Um, J., Lyons, A., Lam, H. K. S., Cheng, T. C. E., \& Dominguez-Pery, C. (2017). Product variety management and supply chain performance: A capability perspective on their relationships and competitiveness implications. International Journal of Production Economics, 187(February), 15-26.

Wu, K. J., Tseng, M. L., Chiu, A. S. F., \& Lim, M. K. (2017). Achieving competitive advantage through supply chain agility under uncertainty: A novel multi-criteria decision-making structure. International Journal of Production Economics, 190, 96-107.

Yiğit, S. (2017). İşletmelerde yeni ürün geliştirmenin rekabet avantajı yaratılması açısından değerlendirilmesi ve cam sektöründe bir uygulama. Ístanbul Üniversitesi Girişimcilik Dergisi, 1(2), 43-54.

Yildirmaz, H. (2008). The Impact of Knowledge Management Capabilities On New Product Development and Company Performance. Unpublished PHD Theses. Yeditepe University, İstanbul, Retrieved 05 February 2020 from: https://tez.yok.gov.tr/

Yıldız, B., \& Çetindaş, A. (2018). Stratejik kaynak kullanımının firma performansı üzerindeki etkisinde tedarik zinciri çevikliğinin aracı rolü. Business \& Management Studies: An International Journal, 6(4), 878-897.

Yıldız, B., \& Çetindaş, A. (2020). Tedarik zinciri entegrasyonunun firma performansı üzerindeki etkisinde tedarik zinciri esnekliği ve tedarik zinciri çevikliğinin aracı rolü. Verimlilik Dergisi, 3, 175-199. 
Yön, I. (2007). Tedarik Zinciri Yönetimi Uygulamalarının Rekabet Gücüne Etkisi. Gaziantep Üniversitesi.

Yusuf, Y. Y., Gunasekaran, A., Musa, A., Dauda, M., El-Berishy, N. M., \& Cang, S. (2014). A relational study of supply chain agility, competitiveness and business performance in the oil and gas industry. International Journal of Production Economics, 147(B), 531543. 